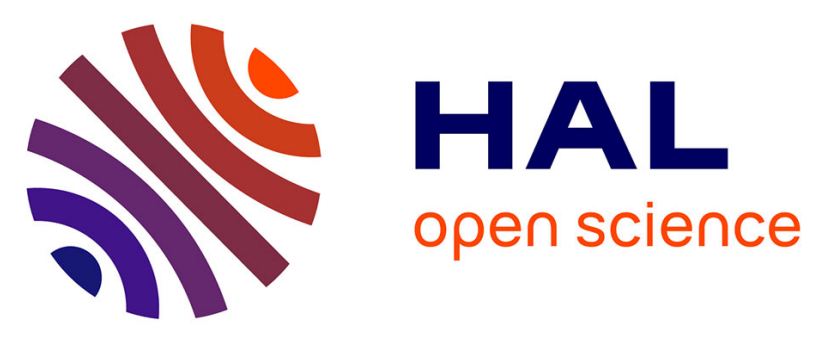

\title{
New histological information on Holoptychius Agassiz, 1839 (Sarcopterygii, Porolepiformes) provides insights into the palaeoecological implications and evolution of the basal plate of the scales of osteichthyans
}

\author{
Jorge Mondéjar Fernández, François Meunier
}

\section{To cite this version:}

Jorge Mondéjar Fernández, François Meunier. New histological information on Holoptychius Agassiz, 1839 (Sarcopterygii, Porolepiformes) provides insights into the palaeoecological implications and evolution of the basal plate of the scales of osteichthyans. Historical Biology, 2020, pp.1-13. 10.1080/08912963.2020.1786552 . mnhn-02976951

\section{HAL Id: mnhn-02976951}

https://hal-mnhn.archives-ouvertes.fr/mnhn-02976951

Submitted on 10 Nov 2020

HAL is a multi-disciplinary open access archive for the deposit and dissemination of scientific research documents, whether they are published or not. The documents may come from teaching and research institutions in France or abroad, or from public or private research centers.
L'archive ouverte pluridisciplinaire HAL, est destinée au dépôt et à la diffusion de documents scientifiques de niveau recherche, publiés ou non, émanant des établissements d'enseignement et de recherche français ou étrangers, des laboratoires publics ou privés. 
New histological information on Holoptychius Agassiz, 1839 (Sarcopterygii, Porolepiformes) provides insights into the palaeocological implications and evolution of the basal plate of the scales of osteichthyans

Jorge Mondéjar-Fernández (1)* and François J. Meunier (2)

(1) UMR 7207 (MNHN-Sorbonne Université-CNRS), Centre de Recherche en Paléontologie - Paris, Département Origines \& Évolution, Muséum national d'Histoire naturelle, CP38, 57 rue Cuvier, 75005, Paris, France email : jorge.mondejar-fernandez@mnhn.fr Orcid ID : https://orcid.org/0000-0003-0853-929X

(2) FRE BOREA 2030 (MNHN - Sorbonne Universités - Univ. Caen Normandie - Univ. Antilles - CNRS - IRD), Département Adaptations du Vivant, Muséum national d'Histoire naturelle, CP26, 43 rue Cuvier, 75231 Paris cedex 05, France email : meunier@mnhn.fr 


\begin{abstract}
The porolepiform sarcopterygian Holoptychius Agassiz, 1839 from the Upper Devonian is one of the most widely found vertebrates in the Palaeozoic fossil record. Holoptychius is considered to display a more ubiquitous mode of life and a greater potential of dispersion than any other sarcopterygian taxon, consistent with its cosmopolitan distribution and profuse fossil record, mainly represented by scales. Previous histological studies on the squamation of Holoptychius have discussed the variable ornamentation of the superficial layer, however the basal plate has been less explored. Here we furnish new histological data on the scales of Holoptychius, focusing on the mineralization rate and organization of the lamellar bone. Ground sections show that the basal plate is made of a stacking of thick collagenous layers with a plywood-like structure. Collagenous fibres are parallel within layers, with two successive layers orthogonally arranged and with every second layer rotated by an angle of $36^{\circ}$. This condition, known as a double-twisted plywood-like organization, is similar to that of other sarcopterygians like Eusthenopteron and extant coelacanths and dipnoans. The new palaeohistological data provide insights into the morphofunctional, palaeoecological and phylogenetical implications of the microstructural characteristics of the scales, adding to our knowledge of the histological diversity of osteichthyans.
\end{abstract}

Running title: Palaeohistology of Holoptychius scales

Keywords: Devonian, Holoptychius, palaeohistology, scale, basal plate, twisted-plywood.

\title{
Word count: 6896
}




\section{Introduction}

The Porolepiformes are an exclusively Devonian clade of sarcopterygians, known from the early Lochkovian to the late Famennian, that populated near-shore and fresh water aquatic environments (Janvier 1996). They share a number of uniquely derived characters with lungfishes and are therefore regarded as their sister group within the Dipnomorpha (Ahlberg 1991). The order Porolepiformes is traditionally divided into two families: the Porolepidae (a possible paraphyletic assemblage of primitive porolepiforms including Porolepis, Durialepis and Heimenia) (Ørvig 1957, 1969; Clément 2004; Mondéjar-Fernández \& Clément 2012; MondéjarFernández et al. 2020) and the Holoptychiidae (comprising notably Holoptychius, Glyptolepis and Laccognathus, among others) (Ørvig 1957; Jarvik 1972; Ahlberg 1992a; Cloutier \& Ahlberg 1996). A third family is now incorporated to the Porolepiformes: the Ventalepididae (Lebedev \& Lukševičs 2018) that includes the enigmatic Ventalepis ketleriensis (Schultze 1980).

Porolepiform remains have been found worldwide, both in Euramerica (e.g., Jarvik 1972; Cloutier \& Schultze 1996; Schultze 2000) and Gondwana (Johanson \& Ritchie 2000; Young et al. 1992, 2010; Johanson et al. 2013). Holoptychiids became highly abundant in fresh water to marginal marine environments during the Middle to Upper Devonian as opposed to 'porolepids' found mainly in fully marine or near-shore environments during the Lower-Middle Devonian (Ahlberg 1992b). Among holoptychiids, Holoptychius is considered to have acquired the largest size, with certain species (e.g., H. giganteus) known from isolated scales and estimated to have reached several meters in length (Janvier 1996). The large size of the scales is coupled with a set of elongate fangs in the jaws, thus confirming that holoptychiids, and more particularly Holoptychius, were among the largest predators in any given Middle-Upper Devonian environment (e.g., Chevrinais et al. 2017). Moreover, given its cosmopolitan distribution and 
profuse fossil record, Holoptychius is considered to display a more ubiquitous mode of life and a greater potential of dispersion than any other sarcopterygian taxon (Cloutier \& Schultze 1996).

The evolutionary history of the Porolepiformes during the Devonian was marked by the transition from a squamation composed of thick and rhombic scales covered with cosmine in the 'porolepids', to thin and rounded imbricate scales lacking cosmine in the more derived holoptychiids (Ørvig 1957; Jarvik 1980; Mondéjar-Fernández \& Clément 2012). The rise of the latter scale morphotype was mirrored by a similar type of ornamentation in the dermal bones of the skull and shoulder girdle displaying an irregular arrangement of tubercles and/or ridges. The rhombic scales of 'porolepids' possess the characteristic peg-and-socket articulation, an oblique articular ridge (or keel) on the internal (or visceral) surface, and reduced overlapped surfaces, whereas in holoptychiids the keel and the peg-and-socket articulation are lost, associated with the acquisition of a rounded outline with large overlapped surfaces. These characters used to be considered as mutually exclusive and characteristic of the two families within the Porolepiformes. However, the condition of Heimenia, displaying rhombic scales in the posterior region of the body and rounded scales anteriorly is informative on the evolutionary transformation of the squamation between 'porolepids' and holoptychiids (Mondéjar-Fernández \& Clément 2012).

Histologically, the rounded scales of holoptychiids can be divided into two well-defined portions: a basal plate composed of lamellar bone overlaid by a superficial layer composed of vascular bone and usually associated with odontogenic components (i.e., dentine and enamel) responsible for the external ornamentation of the scales (Ørvig 1957; Francillon-Vieillot et al. 1990; Mondéjar-Fernández 2018). The scales of Quebecius, Glyptolepis and Laccognathus are ornamented by a combination of ridges and tubercles (Ørvig 1957; Schultze \& Arsenault 1987; Cloutier \& Schultze 1996). The ridges in Glyptolepis (and possibly in Quebecius) are made of dentine covered with enamel (Ørvig 1957). Laccognathus displays rounded dentine tubercles or 
small ridges capped with enamel (Bystrow 1939; Ørvig 1957; Downs et al. 2011; MondéjarFernández 2018). In Ventalepis, the exposed area of certain scales is ornamented by small tubercles made of dentine but no enamel has been identified (Schultze 1980). However, in Holoptychius the superficial ornamentations are reduced to various bony reliefs of the superficial layer of the posterior field; the scales are thus considered to have lost the odontogenic component, with the exception of a narrow anterior area covered with small, probably odontogenic, tubercles occurring in certain specimens (Ørvig 1957; Mondéjar-Fernández \& Janvier 2014). Moreover, in Holoptychius the morphology and ornamentation of the scales varies throughout ontogeny (Ørvig 1957) and may even differ across the body. For instance, the scales of the ventral region in $H$. jarviki exhibit stout bony tubercles that are arranged in rows, whereas dorsal and flank scales display antero-posteriorly oriented bony ridges (Cloutier \& Schultze 1996) (Fig. 1A-B).

While the superficial layer and the various types of odontogenic or osteogenic ornamentations have been widely illustrated and discussed (e.g., Gross 1956; Ørvig 1957), the basal plate of the scales of holoptychiids has been less explored. Here we furnish new histological data on the organization of the basal plate of the scales of Holoptychius, focusing on the mineralization rate and arrangement of the collagen plies of the lamellar bone. Comparison with fossil and extant taxa will shed more light on the morphofunctional, paleoecological and evolutionary implications of the peculiar organization of the lamellar bone of the basal plate of the scales of holoptychiids, sarcopterygians, and osteichthyans more broadly.

\section{Material and methods}

\section{Material}


The fossil scale material consists of trunk scales of Holoptychius sp. found free (MNHN, URSS 5075) from the Frasnian of Latvia ("Nadmeshi beds"), or enclosed in sediment (donated by the late Pr. T. Ørvig) from the Frasnian-Famennian of Greenland, and isolated scales of Holoptychius cf. nobilissimus (MB.f. 1994.1) from the Givetian-Frasnian of Latvia (Fig. 1). All the fossil material is housed at the Muséum national d'Histoire naturelle (MNHN) in Paris, France.

\section{Methods}

The fossil material was embedded in polyester resin (GBS 1; Brot) and sectioned for study. The various sections were ground and polished to a thickness of $60-80 \mu \mathrm{m}$ and observed under transmitted natural light with an Olympus BX51 microscope. Pictures were taken with a digital camera Olympus Camedia C-5060 and finalized in Adobe Photoshop.

Ground sections are registered in the histological collection of the MNHN: MNHN-FHISTOS 2736 (T. Ørvig's specimens of Holoptychius sp. from Greenland), MNHN-F-HISTOS 2737 to 2739 (Holoptychius sp. from Latvia) and MNHN-F-HISTOS 2740 (Holoptychius cf. nobilissimus from Latvia).

\section{Remarks}

The scales of Holoptychius were initially described by Agassiz (1833-44) as rounded, ornamented by undulating furrows or ridges and small associated tubercles. Such description has turned out to be too broad and matches the general morphology of the scales of many other sarcopterygian taxa (e.g., Janvier 1996; Johanson \& Ritchie 2000). However, in depth observations and the combined occurrence of diagnostic features from the external and internal (or visceral) surface of the scales now allows to confidently assign isolated material to Holoptychius (e.g., Miller \& Brazeau 2007; Mondéjar-Fernández \& Janvier 2014). In contrast to other round-scaled Devonian sarcopterygians, the scales of Holoptychius are characterized by an 
external ornamentation composed of undulating stout bony ridges, that could be associated with a fan of small tubercles anteriorly, and by the lack of any ornamentation of the internal surface (Fig. 1D,F), as opposed to other taxa that display narrower and straighter ridges in the exposed area (e.g., Devonian actinistians) (Forey 1998) or a drop-shaped boss in the internal surface (e.g, rhizodonts and tristichopterids) (Jarvik 1980).

During the $19^{\text {th }}$ century, the case of systematic attribution of any given similar scale (either isolated or in articulation) to Holoptychius resulted in the publication of a myriad of Holoptychius species. Cloutier \& Schultze (1996) critically reviewed the taxonomy of the genus and noted that only three among the twenty-four known species of Holoptychius were known from cranial material (H. nobilissimus Agassiz 1839, H. flemingi Agassiz 1843, and H.jarviki Cloutier \& Schultze 1996); for ten of the remaining twenty-one, the species name was erected based on a single scale. Since then, systematic attribution of fossil remains to Holoptychius has been more careful and relies more on non-scale-based characters, such as cranial and postcranial skeletal features (e.g., H. bergmanni, Downs et al. 2013). It is thus currently difficult to reliably assign isolated scales to a given Holoptychius species and as such our description of the material will remain limited to the generic level.

\section{Histological description}

The scales of Holoptychius are round and imbricate (Fig. 1). Each scale shows an anterior field (or overlapped area), overlaid by the neighbour anterior, dorsal and ventral scales, and a posterior field (or exposed area) with an external ornamented surface (Fig. 1B,C,E). The ground sections (Figs 2,3) confirm that the scales are constituted of two superimposed portions: $i$ ) a relatively thick basal plate formed of stacked and parallelly-aligned collagenous lamellae (bp, Figs 2, 3), 
and ii) an overlaying superficial bony layer with numerous vascular canals (sl, Figs 2, 3). This superficial layer totally lacks odontogenic structures in our material, the ornamentation being solely represented by bony longitudinal ridges (Figs 1B, 2B,C, 3). The lower surface of the scales is smooth and regular (Fig. 1D,F).

\section{Superficial layer}

The superficial layer is constituted of a vascularised cellular bony tissue (vb, Figs 2, 3). Numerous vascular canals and cavities are seen, especially in the region close to the basal plate (vc, Figs 3, 4A). Certain vascular canals and cavities can result from remodelling processes (Fig. 4B). Numerous star-shaped osteocytic lacunae (Fig. 4B) with ramified cytoplasmic extensions (i.e., osteocytic canalicles) are present (Fig. 4C). The external surface of this osseous layer is irregular as a result of the bony reliefs (Figs 1C,E,G, 2B-C, 3).

\section{Basal plate}

The basal plate is constituted of a thick staked lamellar bone (lb, Figs 2A-B, 3) histologically and topologically called isopedine (Pander 1856; Gross 1956; Meunier 1987; Francillon-Vieillot et al. 1990). The basal plate is crossed by several more or less parallel ascending vascular canals (Figs 3, 4D) that originate from the lower surface of the scale (Fig. 2A). Some of these vascular canals can merge with the vascular network of the superficial bony layer (Fig. 3).

Vertical sections reveal that the basal plate is made of lamellar bone composed of relatively thick layers of horizontal collagen fibres with the existence of a pattern repeating every five layers (Fig. 5B, C). The average thickness of each layer is about $18-23 \mu \mathrm{m}$. Elongate osteocytes (elasmocytes sensu Meunier 1984; Francillon-Vieillot et al. 1990), are inserted between the collagenous layers, with their cytoplasmic processes extending along the collagen 
fibres (Fig. 4E, 5C). The collagen fibres are arranged as bundles composed of collagenous fibrils. Seen in cross sections, these bundles form small rectangles with round angles (Fig. 5A).

The basal plate is thus made of isopedine with superimposed layers of parallel fibres arranged in a relatively complicated network. An oblique section shows the varying orientations of the fibres, resulting in arciform patterns (Fig. 5C). Combined with the observations in vertical section (Fig. 5B), these patterns allow us to infer the three-dimensional organization of the basal plate. The fibres of each pair of successive layers (odd and even) are roughly orthogonal. However, every second layer rotates by discrete steps with a small angle (approximately $36^{\circ}$ ) around a vertical axis perpendicular to the superimposed layers (Fig. 5E). This structural arrangement results in a right-handed helicoidal structure with a repetitive pattern every five layers (Fig. 5B, F). The intersection of the arciform motifs (Fig. 5D) thus highlights the occurrence of a double system of layers intermingled with one another known as a doubletwisted plywood organization (Giraud et al. 1978a,b). Some relatively thin ascending fibrillary structures (most probably collagenous fibrils) perpendicular to the layers of the basal plate (Fig. 4D) can also occur, filling the space between the horizontal layers.

The lower surface of the basal plate is regular and straight (Fig. 2), which indicates that the collagenous layers of the isopedine were completely and homogenously mineralized throughout their whole thickness.

\section{Discussion}

\section{On elasmoid scales}

Bertin (1944) introduced the term elasmoid scale to describe the round scales of osteichthyans. Elasmoid scales (from the Greek č $\lambda \alpha \sigma \mu \alpha$ or elasma meaning lamella or plate-like) are flexible and relatively thin imbricated scales in which the anterior region is deeply embedded in the 
dermis and the posterior region widely overlaps the lateral and anterior fields of the neighbouring scales. Histologically, elasmoid scales are composed of two parts: $i$ ) a relatively thin, mineralized, and ornamented superficial layer and $i$ ) a thick basal plate made of collagen lamellae with different orientations of the fibres in successive layers (e.g., Williamson 1851; Goodrich 1907; Francillon-Vieillot et al. 1990). Elasmoid scales occur mainly in teleosts and amiids but they are not restricted to the Actinopterygii since the scales of extant sarcopterygians (e.g., Latimeria, lungfishes, and gymnophionan tetrapods) are also considered elasmoid scales (Smith et al. 1972; Castanet et al. 1975; Miller 1979; Meunier \& François 1980; Zylberberg et al. 1980; Zylberberg 1988; Meunier \& Zylberberg 1999; Zylberberg \& Wake 1990; Hadiaty \& Rachmatika 2003; Meunier et al. 2008). An elasmoid scale is thus a scale morpho- and histotype that is widely spread and convergently acquired in osteichthyans (e.g., Francillon-Vieillot et al. 1990; Schultze 1977, 2015) (Fig. 6).

Microstructurally, the rounded scales of Holoptychius with their superficial bony layer overlaying a basal plate with a lamellar organization of its collagen fibres can thus be ascribed to the elasmoid type. However, elasmoid scales have been traditionally characterized by a reduced thickness and mineralization rate, since the basal plate of all extant taxa displaying elasmoid scales is either totally or greatly unmineralized (e.g., teleosts). Nevertheless, elasmoid scales are also known to occur among extinct taxa and, in these cases, the basal plate is generally fully mineralized. Fossil osteichthyans with rounded scales that match the elasmoid type include both actinopterygians (e.g., the amiid Amia robusta, Meunier \& Poplin 1995; the teleosts Pachycormus, Leptolepis, Laelichthys, Meunier \& Brito 2004) and sarcopterygians (e.g., the onychodont Selenodus, Mondéjar-Fernández 2020; the actinistian Miguashaia, J. MondéjarFernández et al. in prep; the porolepiforms Holoptychius, Laccognathus and Glyptolepis, Gross 1956; Ørvig 1957, this study; the dipnoans Phaneropleuron and Scaumenacia, Ørvig 1957; the rhizodont Barameda, Long 1989; the 'osteolepiform' Eusthenopteron, Zylberberg et al. 2010). 
The mineralized basal plate of these taxa represents the primitive state from which the unmineralized condition of their closely-related extant forms (e.g., amiids, teleosts, coelacanths and dipnoans) certainly evolved. Moreover, in certain elasmoid scales, such as in coelacanths, the superficial layer can be ornamented by odontogenic tubercles or ridges, regardless of the mineralization state of the basal plate. Elasmoid scales are thus no longer limited to the largely unmineralized scales of extant osteichthyans lacking odontogenic components but should rather describe round, imbricated scales with a lamellar structure of the basal plate, irrespective of its mineralization state.

\section{Isopedine versus elasmodine}

The term isopedine was coined by Pander (1856) to describe the lamellar bone from the base of the scales and bones of sarcopterygians and 'agnathans'. The term was reprised by Gross (1956) who clearly illustrated that isopedine is made of osseous lamellae composed of collagen bundles whose direction change from layer to layer. The mineralized collagen fibres cross at a right angle or at slightly acute angles and bone cells are present between the bundles but very rarely within them. This arrangement of the collagen plies constitutes a plywood-like structure (Meunier \& Géraudie 1980). Isopedine is considered osteogenic in nature and thus synonym to lamellar bone (Francillon-Vieillot et al. 1990; Sire 1990).

Elasmodine was introduced by Schultze (1996) to characterize the basal plate of the elasmoid scales of actinopterygians (including the amioid scales of amiids and the cycloid/ ctenoid scales of teleosts). Schultze justified his claim stating that the partially mineralized elasmodine of derived actinopterygians was different from the fully mineralized isopedine of basal actinopterygians ('palaeonisciforms') and sarcopterygians, and that the modalities and role of Mandl's corpuscles in the mineralization of the elasmoid scales were not equivalent to that of ganoid and cosmoid scales with isopedine. Sire $(1989,1990)$ reported that in Polypterus, a 
relatively thin plywood-like structure occurs between the overlying dentine layer and the underlying bony basal plate. This structure was called 'elasmodine' and was considered to be of odontogenic originSire \& Huysseune (2003) and Sire et al. (2009) then used 'elasmodine' to describe the poorly mineralized basal plate of extant sarcopterygians (coelacanths and dipnoans), thus considering that the plywood-like tissue of these taxa was derived from a putative layer of lamellar dentine present in the common ancestor of osteichthyans (Sire et al. 2009). However, it has been shown that the 'elasmodine' of Polypterus forms before the dentine and mineralizes slowly with the help of Mandl-like corpuscles (Daget et al. 2001, fig. 6) as in amiids and teleosts (Meunier 1981; Schönbörner et al. 1981; Zylberberg et al. 1992; Meunier \& Poplin 1995), refuting its odontogenic origin.

The proposed homology between the unmineralized basal plate of extant sarcopterygians with the thin 'elasmodine' of polypterids is problematic and fossil evidence does not confirm this bold prediction. Palaeohistological data (e.g., Mondéjar-Fernández \& Clément 2012; Qu et al. 2013) and phylogenetic reconstructions (e.g., Giles et al. 2017; Clement et al. 2018) (Fig. 6) do not allow to claim that the unmineralized basal plate of extant coelacanths (Latimeria) and lungfishes (Neoceratodus, Protopterus and Lepidosiren) corresponds to 'elasmodine' as described in Polypterus. In these taxa, the basal plate consists of an irregularly mineralized lamellar bone (e.g., Smith et al. 1972; Castanet et al. 1975; Meunier and François, 1980; Meunier, 1980), topologically and structurally similar to the isopedine found in fossil taxa (e.g., early actinistians like Miguashaia, dipnomorphs like Porolepis and Dipterus, and tetrapodomorphs like Eusthenopteron). We thus consider that the introduction of 'elasmodine' is an unnecessary complexification and confusing terminology. We favor the use of the term isopedine to describe the lamellar tissues of the scales of osteichthyans, composed of variably mineralized lamellar bone with a plywood-like structure of the collagen plies. 


\section{Evolutionary significance of the plywood-like structures in the dermal skeleton of vertebrates}

Many of the plywood-like structures occurring in the dermal skeleton of vertebrates have been characterized as isopedine. Structurally, isopedine is thus one of the oldest histological features of the vertebrate dermal skeleton, forming the lowest layer of the primitive bipartite skeleton consisting of a superficial layer ornamented with odontogenic products (i.e., odontodes made of dentine and enamel) overlying an osteogenic laminated basal layer (Keating \& Donoghue 2016). However, the structure of the isopedine varies across taxa displaying more or less important specializations of the plywood-like organization (e.g., orthogonal or twisted plywood), a lack of incorporated cells (cellular or acellular isopedine), and regression or even lack of a mineral component (partially or unmineralized isopedine) (Francillon-Vieillot et al. 1990) (Fig. 6).

The evolutionary history of isopedine can be traced back to the earliest vertebrates. Pteraspidomorphs (including the arandaspids, astraspids and heterostracans) possess an acellular isopedine composed of an orthogonal arrangement of collagen plies anchored to the dermis by Sharpey's fibres (Donoghue \& Sansom, 2002; Sansom et al. 2005; Donoghue et al. 2006; Sire et al. 2009; Keating et al. 2015; O’Shea et al. 2019). The small scales of anaspids present a basal layer of vascularized, acellular lamellar bone, usually identified as 'aspidine' (Gross 1938, 1958), but bearing more similarities with isopedine (Gross 1958; Blom et al. 2001; Donoghue \& Samson 2002; Donoghue et al. 2006; Keating \& Donoghue 2016). Thelodont scales do not possess isopedine and solely retain a superficial layer of odontodes with associated bone of attachment (Märss et al. 2007; Sire et al. 2009; Keating et al. 2015). The dermal skeleton of galeaspids is also greatly reduced, lacking odontogenic components, and displays a type of lamellar bone with an orthogonal plywood-like arrangement of thin collagen fibrils termed galeaspidin (Wang et al. 2005; Donoghue et al. 2006; Qu et al. 2013) that is comparable to isopedine (Gross 1968a; Keating et al. 2015). In osteostracans, the isopedine lacks cells (O'Shea 
et al. 2019) and forms a homogenous basal layer with an orthogonal arrangement of thick collagen bundles (Gross 1935, 1961; Denison 1947, 1951).

In gnathosthomes, a lamellar structure can be found in the basal-most layer of the dermal bones and scales of 'placoderms' (Gross 1973; Burrow \& Turner 1999; Giles et al. 2013) but it is not clear whether it can be considered isopedine or not. A plywood-like tissue forms the base of the scales referred to some 'acanthodians' (Gross 1947, 1971) and putative early chondrichthyans (Ørvig 1966). Otherwise, the dermal skeleton of stem and crown chondrichthyans is characterized by a significant reduction of its osteogenic components, including a basal layer of lamellar bone, and the sole retention of the superficial odontodes with associated bone of attachment forming the characteristic placoid scales of extant chondrichthyans (Agassiz 1833-44, Williamson 1849; Goodrich 1907).

\section{Homologies of organization of the basal plate of the scales of osteichthyans}

The histological variability and evolution of the basal plate of the scales of osteichthyans have been difficult to decipher. The main source of problems originates in a partial understanding of the different types of lamellar structures in the scales resulting in an oversimplification of the histological nature of the basal plate. Thus, in osteichthyans, the occurrence and distribution of isopedine is puzzling and its evolutionary history might be more complex than previously expected.

Many stem-osteichthyans from the Late Silurian-Early Devonian (e.g., Andreolepis, Dialipina, Ligulalepis, Lophosteus, Naxilepis, Orvikuina, and Terenolepis) (Friedman \& Brazeau 2010; Burrow \& Turner 2012) (Fig. 6) are known mainly from isolated scale material that has been histologically surveyed, providing key information on the early establishment of the osteichthyan squamation. In the scales of Andreolepis, Lophosteus, Ligulalepis, Naxilepis and Terenolepis the basal-most layer is made of a homogenous cellular lamellated bone, with 
numerous Sharpey's fibres (Gross 1968b, 1969; Schultze 1968; Wang \& Dong 1989; Burrow 1995; Jerve et al. 2016) but no distinctive plywood-like organization appears to be present. Orvikuina and Dialipina display a basal plate composed of an acellular lamellated bone (Schultze 1968, 1977) but whereas in Orvikuina it is poorly preserved, in Dialipina a plywoodlike organization might have been present (Schultze 1968, pl.4). In the lower jaw of Guiyu (Zhu et al.2009) a thick layer of lamellated bone occurs underneath the dentine, but its structure is unclear.

The earliest undisputed account of a plywood-like structure in a stem-osteichthyan is found in Psarolepis, however not in the basal plate but in the keel of its rhombic scales, which is composed of isopedine with an orthogonal arrangement of collagen bundles composed of small fibrils (Qu et al. 2013). The rest of the scale base consists of cellular pseudo-lamellar bone or parallel-fibred bone penetrated by Sharpey's fibres. Therefore, with the exception of Psarolepis, it is difficult to ascertain whether isopedine occurred in stem-osteichthyans without better imagery and more detailed histological information. In taxa described as presenting 'lamellar bone' in their scales, the absence of a clear plywood-like structure might indicate that the lamellated bone was rather a type of pseudo-lamellar bone or parallel-fibred bone, different from isopedine (sensu Francillon-Vieillot et al. 1990).

Lamellar bone is widespread and homogenously distributed among sarcopterygians and isopedine has been widely used to label the osseous basal plate of their scales (e.g., onychodonts, actinistians, porolepiforms, dipnoans, 'osteolepiforms' and ‘elpistostegalians') (Gross 1956; Ørvig 1956; Forey 1998; Witzmann 2011) (Fig. 6). The occurrence of cells located between the isopedine layers is also common, however the arrangement of the plywood-like structure is variable across taxa. In the porolepiform Heimenia, the rounded scales from the anterior region of the body display a twisted plywood, whereas the rhombic scales from the posterior region show a more orthogonal arrangement of the collagen plies (Mondéjar-Fernández \& Clément 
2012). When compared with the cosmoid scales of Porolepis, Osteolepis and Megalichthys

(Gross 1956, 1966) and the rhombic scales of Panderichthys (Witzmann 2011), it appears that an orthogonal arrangement is more commonly found in rhombic scales. On the other hand, a twisted arrangement occurs in the rounded scales of the onychodont Selenodus (Mondéjar-Fernández 2020), the 'osteolepiform' Eusthenopteron (Zylberberg et al. 2010), the porolepiform Holoptychius (Fig. 5), and probably the dipnoan Dipterus (Gross 1956), which indicates that a twisted plywood might be more frequently correlated with a rounded scale morphotype, irrespective of the retention of cosmine (Fig. 6). An orthogonal arrangement of isopedine can thus be considered primitive in sarcopterygians relative to the derived twisted condition.

In the case of actinopterygians, the depiction of the basal plate of the scales has been somewhat overlooked and poorly illustrated in many fossil specimens; consequently much of the paleohistological information is either confusing or unreliable. Scales are unknown in Meemannia (Zhu et al. 2006, 2010) but in the dermal bones the basal-most layer was described and illustrated as 'lamellar bone', however it does not display a clear plywood-like structure (Qu et al.2013). In Moythomasia and Mimipiscis, the scale base was illustrated as a homogenous cellular lamellated bone penetrated by Sharpey's fibres, but its microstructure was not figured (Jessen 1968; Gardiner 1984). The 'lamellar bone' in these taxa does not clearly show a plywood-like structure and is probably pseudo-lamellar bone instead (Francillon-Vieillot et al. 1990). Cheirolepis is one of the few examples where the bony base is certainly not made of a plywood-like structure and thus isopedine can be confidently considered absent (Gross 1966; Zylberberg et al. 2015). In Polypterus, the bony base of the scales has been described as constructed by homogenous pseudo-lamellar bone (Goodrich 1907; Sire et al. 2009). The only plywood-like structure present is the thin isopedine layer underneath the dentine (Sire 1989), which has also been identified in a variety of fossil polypterids: Dagetella (Gayet \& Meunier, 1992), Latinopollia (Meunier \& Gayet, 1996; Meunier \& Gayet, 1998), and Bawitius (Meunier et 
al. 2016). A twisted plywood-like structure with an irregular mineralization rate has been described in the basal plate of the scales of the holostean Amia (Meunier 1981; Meunier \& Poplin 1995), probably the caturid Caturus (Schultze 1966), and numerous teleosts (Meunier \& Géraudie 1980; Meunier 1984; Neville 1993; Meunier \& Brito 2004) with a left-handed rotation, whereas as in the pleuronectiform Pleuronectes microcephalus a right-handed rotation has been observed (Darke 1986).

The disjunct phylogenetic distribution of isopedine in osteichthyans and the variable orientation of the collagen layers across taxa clearly point towards a convergence between plywood-like structures in sarcopterygians and actinopterygians (Fig. 6). Sarcopterygian fishes display a consistently well-developed lamellar bone layer in all surveyed taxa; isopedine can thus be considered a primitive shared feature of the Sarcopterygii. However, the paleohistological data suggest that the occurrence of isopedine is irregular in actinopterygians, complicating its use as a reliable phylogenetic character. Isopedine may thus not be a shared feature of actinopterygians since its disappearance from the basal plate might have occurred early on in their evolutionary history (e.g., Meemannia and Cheirolepis). As seen in the scales of several primitive actinopterygians (e.g., Moythomasia, Mimipiscis, Polypterus), other types of bony tissues replaced the lamellar bone from the basal plate but these can hardly be considered isopedine. A lamellar organization of the basal plate might then have been acquired convergently in amiids and teleosts but whether these plywood-like structures are derived from those of polypterids or represent a convergent acquisition is still unclear.

\section{Histology of the basal plate of Holoptychius and comparisons}

The basal plate of the scales of holoptychiids has only been briefly histologically surveyed in Holoptychius, Glyptolepis and Laccognathus. In Laccognathus, the arrangement of the collagen plies appears orthogonal as illustrated by Gross (1956, fig. 57). For Glyptolepis, Ørvig (1957, p. 
389) stated that the organization of the isopedine layer is 'indistinguishable' from that of Holoptychius, without further descriptions. The basal plate of Ventalepis was also illustrated by Schultze (1980, fig. 13) but its structure was not described. Moreover, it has been noted that the thickness of the basal plate relative to the superficial layer increased during the transition from the rhombic scales of 'porolepids' (e.g., Porolepis, Heimenia) (Mondéjar-Fernández \& Clément 2012) to the rounded scales of holoptychiids, in which the basal plate of Laccognathus is relatively thinner to that of Holoptychius (Ørvig 1957; Mondéjar-Fernández 2018, fig. 3). The increase in the thickness of the isopedine layer relative to the rest of the scale can be explained in Holoptychius by the disappearance of the odontogenic component of the superficial layer compared with the cosmoid scales of 'porolepids'. This evolutionary trend in holoptychiids has palaeocological implications (see below) and might be explained by the capacity of the plywoodlike structure of the basal plate to be both flexible and resistant, as opposed to thick superficial layers with well-developed osseous and odontogenic components.

Our new data reveal that in Holoptychius the collagen fibrils are gathered into bundles (or fibres) forming layers which cross at an angle of roughly $90^{\circ}$ and every second layer is rotated of approximately $36^{\circ}$, with a pattern repeating every five layers. This peculiar arrangement of the collagen plies is not simply orthogonal but it can rather be described as a double-twisted plywood (Fig. 5). To our knowledge, this is the second example of such an elaborate network described in the scales of a extinct osteichthyan. A double-twisted plywood organization of the basal plate was first described in the scales of the 'osteolepiform' Eusthenopteron (Zylberberg et al. 2010). A repetitive pattern every five layers can also be observed in the scales of the dipnoan Dipterus (Gross 1956, fig. 71D), suggesting a twisted condition, similar to that revealed in Holoptychius. Similarly, this three-dimensional organization of the scales of Holoptychius recalls the double-twisted plywood organization found in the scales of the extant coelacanths Latimeria chalumnae (Giraud et al. 1978a,b) and L. menadoensis (Meunier et al. 2008); the sole difference 
is the rotation angle that is about $36^{\circ}$ in Holoptychius instead of $27^{\circ}$ in L. chalumnae (Giraud et al. 1978a,b), which has a repetitive pattern every seven layers. A double-twisted plywood has also been described in the basal plate of living lungfishes but with a mean rotation angle of $30^{\circ}$ in Neoceratodus forsteri and $35-36^{\circ}$ in Protopterus annectens and Lepidosiren paradoxa (Meunier \& François 1980).

The basal plate of the scales of Holoptychius is fully mineralized, as in many other extinct sarcopterygians (e.g., Porolepis, Heimenia, Dipterus, Osteolepis, Megalichthys, Eusthenopteron, Panderichthys) (Goodrich 1907; Gross 1956; Zylberberg et al. 2010; Witzmann 2011; Mondéjar-Fernández \& Clément 2012), but contrary to the basal plate of the scales of living coelacanths and lungfishes (Smith et al. 1972; Kemp et al. 2015). In Latimeria, the basal plate remains widely unmineralized (Castanet et al. 1975; Meunier et al. 2008), except at its contact with the superficial layer as thin mineralized globules (Meunier \& Zylberberg 1999). In dipnoans, the basal plate is completely unmineralized (Neoceratodus) or partly mineralized (Lepidosiren and Protopterus) (Günther 1871; Brien 1962; Castanet et al. 1975; Meunier \& François 1980). Lack of mineralization was also hypothesized to explain the absence of preserved isopedine in the fossil scales of the early tetrapod Tulerpeton (Mondéjar-Fernández et al. 2014). Incompletely mineralized basal plates with a plywood-like structure are thus common among sarcopterygians and also occur in actinopterygians, such as the amiids Amia calva (Meunier 1981) and Amia robusta (Meunier \& Poplin 1995) (Fig. 6). These evolutionary changes of the mineralization rate of the isopedine might be due to convergent heterochronous processes (e.g., paedomorphosis) in osteichthyans (Meunier 1987) linked to a general trend of reduction of the ossification of the dermal skeleton in vertebrates since the Palaeozoic (e.g., Smith \& Hall 1990; Donoghue \& Samson 2002).

The presence of cells in the isopedine has also been confirmed in Holoptychius (Figs 4, 5). These cells are flat, elongated, spindle-shaped osteocytes (elasmocytes sensu Meunier 1984; 
Francillon-Vieillot et al. 1990), with cellular expansions localized essentially in their extremities (Castanet et al., 1975, fig. 12; Zylberberg et al., 2010, fig. 3E). Elongate osteocytes occur between the collagen layers in the basal plate of rounded scales, like in Latimeria (Géraudie \& Meunier 1981), Dipterus (Gross 1956), and Laccognathus (Mondéjar-Fernández 2018). In elasmoid scales, the direction of the cellular expansions of the osteocytes is mainly parallel to the collagen bundles and as such they differ from the osteocytes found in other bony tissues, which typically display star-shaped cellular processes distributed all around the cell lacunae.

Thin ascending collagenous fibrils perpendicular to the remaining large collagenous layers of the basal plate have been found in Holoptychius (Figs 4D). These anchoring fibrils may represent Sharpey's fibres but also bear similarities with the so-called TC fibres described in the scales of several actinopterygian teleosts (e.g., Carassius) (Onozato \& Watabe 1979; Zylberberg \& Nicolas 1982, fig. 1; Zylberberg et al. 1992, fig. 3). In teleosts, TC fibres appear to be involved in the first stage of mineralization (Schönborner et al. 1979; Zylberberg \& Nicolas 1982). Thin ascending fibrils have also been described in the scales of Latimeria chalumnae (Giraud et al. 1978a,b) where they constitute a binding material that strengthen the cohesion of the plywood, similar to the role of Sharpey's fibres. We propose that in the scales of Holoptychius, these fibrils could have assumed both functions.

\section{Palaeocological implications for Holoptychius}

Thin and flexible rounded scales have been morphofunctionally interpreted as an evolutionary answer to the problem of lightening of the body and as an improvement of the swimming capacities in fishes (e.g., Burdak 1979; Belles-Isles 1992; Gemballa \& Bartsch 2002). In the case of porolepiforms, the rounded scales of holoptychiids (e.g., Holoptychius, Laccognathus, Glyptolepis) contrast with the thick and densely mineralized rhombic scales of 'porolepids' (e.g., Porolepis, Heimenia) and other primitive sarcopterygians, usually reconstructed as almost 
exclusively benthonic fishes with reduced abilities to reach high swimming speeds (Clément 2004). However, irrespective of the scale morphology, the fusiform body of porolepiforms, the posteriorly displaced median fins, and the heterocercal caudal fin are congruent with a predatory behaviour, both in 'porolepids' and holoptychiids (Ahlberg 1992b; Clément 2004).

The proposed general body outline, swimming style, and size range of Holoptychius allow us to clearly identify this taxon as an ambush predatory fish capable of performing speed bursts (Ahlberg 1989; Belles-Isles 1992; Clément 2004; Mondéjar-Fernández \& Clément 2012) (Fig. 1A). A modern analogue to this behavioural and anatomical profile can be found in the extant osteoglossomorph actinopterygian Arapaima gigas (Pirarucú), one of the largest fresh water fish in the world (up to 3 meters in length) from the Amazon Basin in South America (Nelson 2006). The head morphology, relative position of the eyes and mouth, and the general proportions of the body are similar to those of Holoptychius (Fig. 1A). The large elasmoid scales of A. gigas are rounded and display a well-developed basal plate with a lamellar organization (Meunier 1984; Sherman et al. 2017) (Fig. 6). A similar configuration of imbricate rounded scales can be found in large extant sarcopterygians (reaching more than 1.5 meters in length) like the coelacanth Latimeria found in the deep waters of the eastern coast of South Africa and the Mozambique Channel (L.chalumnae) and Indonesia (L.menadoensis) (Roux 1942; Smith et al. 1972; Castanet et al. 1975; Giraud et al. 1978a,b; Meunier et al. 2008) and the dipnoan Neoceratodus forsteri found in the freshwaters of the coastal rivers of Queensland, Australia (Kerr 1955; Meunier \& François 1980; Kind 2011).

The elasmoid scales of osteichthyans display large overlapping surfaces and are flexible in all directions, increasing the whole mobility of the fish during swimming, as opposed to ganoid (e.g., 'paleonisciforms', Lepisosteus and Polypterus) or cosmoid (e.g., primitive sarcopterygians) scales with reduced overlapping surfaces, increasing lateral curvature but diminishing vertical flexion (Gemballa \& Barstch 2002). However, trunk flexibility is not only 
linked to the presence of rounded scales but also to a lesser degree of overlapping and to a lower body thickness invested by scales in transverse section. Many lungfishes, either extinct (e.g., Dipterus, Chirodipterus, Griphognathus) or extant (e.g., Neoceratodus), present an extensive overlapping pattern of the scales (Kerr 1955; Pridmore \& Brawick 1993) in which the trunk is protected by up to eight layers of rounded scales. Moreover, scales from the anterior portion of the trunk are slightly more elongate and quadrangular (e.g., Neoceratodus) and thus constrain the lateral bending of the body more than small scales, resulting in a limited lateral flexibility. In other sarcopterygians like Latimeria (Millot \& Anthony 1958, 1978) and Holoptychius (Jarvik 1980; Mondéjar-Fernández \& Clément 2012), as well as in Arapaima and many other actinopterygians (Burdak 1979), the mean number of protective layers is only three and the scales are relatively less elongate than in dipnoans, thus suggesting a higher degree of lateral torsion of the trunk.

The squamation also has a crucial protective role in vertebrates and its study reveals different strategies developed to cope with potential predators. In fishes adapted to escape from predators, the structure of the scales will be correlated with an enhancement in flexibility and lightness, whereas in armoured, more protected fishes the scales will have higher resistance to fracture and average bending stiffness (Burdak 1979; Bruet et al. 2008; Song et al. 2011; Zimmerman et al. 2013; Sherman et al. 2017). A comparison of Holoptychius with Arapaima and Latimeria reveals that all these taxa possess a plywood-like structure of the basal plates of their scales. Mechanical experiments (Yang et al. 2013; Zimmermann et al. 2013; Sherman et al. 2017) have demonstrated that a plywood-like arrangement of the collagen fibres in the scales of Arapaima and Latimeria is highly resistant to crack propagation caused by the attack of predators. In the case of Arapaima, the mineralized external layer resists the penetration of teeth from its main predator, the piranha, while the plywood-like structure of the basal plate provides strength and stiffness to accommodate the deformation. An external ornamentation of 
longitudinal ridges and/or tubercules, either bony as in Holoptychius, or odontogenic as in Latimeria, has also been proven to actively contribute to flexion of the body during swimming or in case of an attack, minimizing the tensile stresses acting on the scales (Song et al. 2011; Sherman et al. 2017).

The organization of the basal plate in extant osteichthyans has revealed its role in the protection against predators. Histological structure thus mirrors ecological behaviour and allows us to confidently propose palaeoecological strategies in extinct taxa based on features from the squamation. Shark bite marks found on L. chalumnae suggest that sharks may be one possible predator of Latimeria (Fricke et al. 1991; Forey 1998; Fricke \& Hissmann 2000), making the squamation of coelacanths suitable to successfully defend them from many small sharks, but not optimal to cope with more powerful bites from larger ones. In the case of Holoptychius, bite marks have been found in several large scales from the Middle to Upper Devonian of the Baltic States and Russia (Lebedev et al. 2009). The marks correspond to gaps left by the teeth of predatory sarcopterygians co-occurrying in the same palaeoenvironment, such as 'osteolepiforms' (e.g., Jarvikina) but also other holoptychiids (probably Holoptychius), thus indicating that sarcopterygian fishes were the main predators of Holoptychius and that intrageneric predation might also have occurred at different stages of development of certain Holoptychius species (Lebedev et al. 2009). Our new data suggests that the plywood-like organization of the basal plates of the scales of Holoptychius, similar to those of Latimeria and Arapaima, might have provided both resistance and flexibility to the scales in the case of an attack while the bony superficial layer was capable of resisting the penetration of the teeth from predators (e.g., Song et al. 2011). The scales of Holoptychius might have thus been suited for protection from small Devonian predators (e.g., chondrichthyans, 'acanthodians', smaller sarcopterygian fishes or early tetrapods), but not from the powerful bites of larger predators (e.g., ‘placoderms' like Dunkleosteus) (Janvier 1996; Young 2010). 


\section{Conclusions}

Our new data on the organization of the basal plate of the scales of the holoptychiid porolepiform Holoptychius completes previous descriptions of the superficial layer and ornamentation patterns of the exposed area of the scales, adding to our knowledge on the histological diversity of the squamation in sarcopterygians. The basal plate of the scales of Holoptychius is composed of a fully mineralized isopedine in which the collagen layers display a double-twisted plywood arrangement. Among sarcopterygians, this peculiar organization was previously only known in the 'osteolepiform' Eusthenopteron (Zylberberg et al. 2010) but is common in extant forms like the coelacanth Latimeria (Giraud et al. 1978a,b) and the dipnoans Neoceratodus, Lepidosiren and Protopterus (Meunier \& François 1980). Comparisons with modern analogues like Arapaima and Latimeria suggest that the scales of Holoptychius with large overlapped regions and a low degree of imbrication might have been adapted against predators with sharp teeth (small tip radius) (Sherman et al. 2017). The combined occurrence of protective yet flexible scales, with a double-twisted plywood arrangement of the basal plate, coupled with the acquisition of a large size in certain species might have facilitated the cosmopolitanism and versatility of the genus Holoptychius and its establishment as a main predator of coastal and freshwaters environments during the second half of the Devonian period.

The occurrence of elasmoid scales in Holoptychius further confirms that the elasmoid morpho- and histotype appeared convergently in various osteichthyan lineages, including both sarcopterygians (e.g., actinistians, derived dipnomorphs and tetrapodomorphs) and actinopterygians (amiids and teleosts). Our new data on Holoptychius support the idea that the isopedine from the basal plate of extant coelacanths and dipnoans cannot be considered 
homologous to the thin isopedine layer in Polypterus and strongly suggest that the occurrence of a basal plate with a plywood-like structure in Latimeria, Neoceratodus, Protopterus and Lepidosiren corresponds to a retained primitive feature of sarcopterygians. Finally, new palaeohistological data highlight that the importance of the basal plate in the evolution of the osteichthyan squamation has been neglected, mainly based on inaccurate observations, incomplete descriptions, and terminological incoherence, stressing the necessity of in-depth new studies on the evolutionary history of isopedine in vertebrates.

Acknowledgements: We are grateful to Florian Witzmann and to late Prof. Tor Ørvig who provided the fossil material used in this study (Figs 1G, 2C, 3). We thank Severin Morel for preparing the thin sections and Philippe Loubry for taking the photograph in Fig. 1. Thodoris Argyriou is thanked for his help with Greek etymology. We also acknowledge the reviewers Qingming Qu and Ben King whose constructive comments improved this paper.

Disclosure statement. No potential conflict of interest was reported by the authors.

\section{References}

Agassiz L. 1833-44. Recherches sur les Poissons fossiles. 5 Volumes and Atlas. Imprimerie Petitpierre. Neuchâtel.

Ahlberg PE. 1989. Paired fin skeletons and relationships of the fossil group Porolepiformes (Osteichthyes: Sarcopterygii). Zoological Journal of the Linnean Society, 96, 119-166. Ahlberg PE. 1991. A re-examination of sarcopterygian interrelationships, with special reference to the Porolepiformes. Zoological Journal of the Linnean Society, 103, 241-287. 
Ahlberg PE. 1992a. A new holoptychiid porolepiform fish from the Upper Frasnian of Elgin, Scotland. Palaeontology, 35, 813-828.

Ahlberg PE. 1992b. The palaeoecology and evolutionary history of the porolepiform sarcopterygians. In : Mark-Kurik E editor, Fossil Fishes as Living Animals. Academy of Sciences of Estonia, Tallinn, Estonia ; p. 71-90.

Belles-Isles M. 1992. The modes of swimming of sarcopterygians. In : Mark-Kurik E, editor, Fossil Fishes as Living Animals. Academy of Sciences of Estonia, Tallinn, Estonia ; p. 117-130.

Bertin L. 1944. Modifications proposées dans la nomenclature des écailles et des nageoires. Bulletin de la Société Zoologique de France, 69 : 198-202.

Blom H, Märss T, Miller C. 2001. Silurian and earliest Devonian birkeniid anaspids from the Northern Hemisphere. Earth and Environmental Science Transactions of the Royal Society of Edinburgh, 92(3), 263-323.

Brien P. 1962. Etude de la formation, de la structure des ecailles des dipneustes actuels et de leur comparaison avec les autres types d'ecailles des poissons. Annales du Muséum Royal de l’Afrique Centrale, 108: 53-129.

Bruet BJ, Song J, Boyce MC, Ortiz C. 2008. Materials design principles of ancient fish armour. Nature materials, 7(9): 748-756.

Burdak VD. 1979. Morphologie fonctionnelle du tegument écailleux des poissons. La pensée scientifique (In Russian). French translation, 1986, Cybium, 10 (3, suppl.): 1-147.

Burrow CJ. 1995. A new palaeoniscoid from the Lower Devonian Trundle beds of Australia. Geobios MS 19: 319-325

Burrow CJ, Turner S. 1999. A review of placoderm scales, and their significance in placoderm phylogeny. Journal of Vertebrate Paleontology, 19(2): 204-219. 
Burrow CJ, Turner S. 2012. Fossil Fish Taphonomy and the Contribution of Microfossils in Documenting Devonian Vertebrate History. In : Talken JA editor. Earth and Life, International Year of Planet Earth. Springer, Dordrecht. p. 189-223.

Bystrow AP. 1939. Zahnstruktur der Crossopterygier. Acta Zoologica 20, 283-338.

Castanet J, Meunier F, Bergot C, François Y. 1975. Données préliminaires sur les structures histologiques du squelette de Latimeria chalumnae. I - Dents, écailles, rayons de nageoires. In: Coll. Inter. CNRS, "Problèmes actuels de Paléontologie. Evolution des Vertébrés", Paris, 4-9 Juin 1973, p. 159-168 (4 Pl).

Chevrinais M, Jacquet C, Cloutier R. 2017. Early establishment of vertebrate trophic interactions: Food web structure in Middle to Late Devonian fish assemblages with exceptional fossilization. Bulletin of Geosciences, 92(4), 491-510.

Clément G. 2004. Nouvelles données anatomiques et morphologie générale des "Porolepididae" (Dipnomorpha, Sarcopterygii). Revue de Paléobiologie, Genève. Vol. spéc. 9, 193-211.

Clement AM, King B, Giles S, Choo B, Ahlberg PE, Young GC, Long JA. 2018. Neurocranial anatomy of an enigmatic Early Devonian fish sheds light on early osteichthyan evolution. Elife, 7, e34349.

Cloutier R, Ahlberg PE. 1996. Morphology, characters, and the interrelationships of the basal Sarcopterygians. In : Stiassny MLJ, Parenti LR, Johnson GD, editors. Interrelationships of Fishes II. Academic Press, New York. p. 445-479.

Cloutier R, Schultze HP. 1996. Porolepiform fishes (Sarcopterygii). In: Schultze HP, Cloutier R, editors. Devonian fishes and plants of Miguasha, Quebec, Canada. p. 248-270. Dr F. Pfeil, München.

Daget J, Gayet M, Meunier FJ, Sire J-Y. 2001. Major discoveries on the dermal skeleton of fossil and recent polypteriforms: a review. Fish and Fisheries, 2: 113-124. 
Darke W. 1986. Asymmetry and collagen fibre orientation in the basal plate of flatfish

(Pleuronectidae) scales. B.Sc. thesis, University of Bristol, U.K.

Denison RH. 1947. The exoskeleton of Tremataspis. American Journal of Science, 245: 337365.

Denison RH. 1951. The exoskeleton of early Osteostraci. Fieldiana Geology, 11(4) : 199-218.

Donoghue PCJ, Sansom IJ. 2002. Origin and early evolution of vertebrate skeletonization. Microscopy Research \& Technique, 59(5): 352-372.

Donoghue PCJ, Sansom IJ, Downs JP. 2006. Early evolution of vertebrate skeletal tissues and cellular interactions, and the canalization of skeletal development. Journal of Experimental Zoology - Part B: Molecular and Developmental Evolution, 306B: 278-294.

Downs JP, Daeschler EB, Jenkins FA Jr, Shubin NH. 2011. A new species of Laccognathus (Sarcopterygii, Porolepiformes) from the Late Devonian of Ellesmere Island, Nunavut, Canada. Journal of Vertebrate Paleontology, 31, 981-996.

Downs JP, Daeschler EB, Jenkins FA Jr, Shubin NH. 2013. Holoptychius bergmanni sp. nov. (Sarcopterygii, Porolepiformes) from the Upper Devonian of Nunavut, Canada, and a review of Holoptychius taxonomy. Proceedings of the Academy of Natural Sciences of Philadelphia, 162, 47-59.

Forey PL, 1998. History of the Coelacanth Fishes. London: Chapman and Hall. 419 p.

Francillon-Vieillot H, Buffrenil V de, Castanet J, Géraudie J, Meunier FJ, Sire JY, Zylberberg L, de Ricqlès A. 1990. Microstructure and mineralization of vertebrate skeletal tissues. In : Carter JG, editor. Skeletal Biomineralization: Patterns, Processes and Evolutionary Trends. Vol. 1.Van Nostrand Reinhold, New York, USA. p. 471-530.

Fricke H, Hissmann K. 2000. Feeding ecology and evolutionary survival of the living coelacanth Latimeria chalumnae. Marine Biology, 136(2), 379-386. 
Fricke H, Schauer J, Hissmann K, Kasang L0, Plante R, 1991. Coelacanth Latimeria chalumnae aggregates in caves: first observations on their resting habitat and social behavior. Environ. Biol. Fishes 30 (3), 281-285.

Friedman M, Brazeau MD. 2010. A reappraisal of the origin and basal radiation of the Osteichthyes. Journal of Vertebrate Paleontology, 30(1): 36-56.

Gardiner BG. 1984. The relationships of the palaeoniscid fishes, a review based on new specimens of Mimia and Moythomasia from the Upper Devonian of Western Australia. Bulletin of the British Museum (Natural History), Geology 37: 173-428.

Gayet M, Meunier FJ. 1992. Polyptériformes (Pisces, cladistia) du Maastrichtien et du Paléocène de Bolivie. Geobios, mém. sp., 14: 159-168.

Gemballa S, Bartsch P. 2002. Architecture of the integument in lower teleostomes: functional morphology and evolutionary implications. Journal of Morphology, 253: 290-309.

Giles S, Rücklin M, Donoghue PCJ. 2013. Histology of “placoderm” dermal skeletons: Implications for the nature of the ancestral gnathostome. Journal of Morphology, 274(6): $627-644$.

Giles S, Xu GH, Near TJ, Friedman M. 2017. Early members of 'living fossil'lineage imply later origin of modern ray-finned fishes. Nature, 549(7671) : 265-268.

Giraud MM, Castanet J, Meunier FJ, Bouligand Y. 1978a. The fibrous structure of coelacanth scales: a twisted "plywood". Tissue and Cell, 10: 671-686.

Giraud MM, Castanet J, Meunier FJ, Bouligand Y. 1978b. - Organisation spatiale de l'isopédine des écailles du coelacanthe (Latimeria chalumnae, Smith). C. R. Acad Sci., 287: 487-489.

Goodrich ES. 1907. On the scales of fish living and extinct, and their importance in classification. Proceedings of the Zoological Society of London, 47 (4): 751-774.

Gross W. 1935. Histologische Studien am Aussenskelett fossiler Agnathen und Fische. Palaeontographica Abteilung A 83: 1-60. 
Gross W. 1938. Der histologische aufbau der Anaspiden-schuppen. Norsk Geologisk Tiddskrift, 17: 191-195.

Gross W. 1947. Die Agnatben und Acanthodier des obersilurischen Beyrichienkalks. Palaeontographica, 96(A): 91-158.

Gross W. 1956. Über Crossopterygier und Dipnoer aus dem baltischen Oberdevon im Zusammenhang einer vergleichenden Untersuchung des Porenkanalsystems paläozoischer Agnathen und Fische. Kungliga Svenska Vetenskapsakademiens Handlingar, 5(6): 1-140.

Gross W. 1961. Aufbau des Panzers obersilurischer Heterostraci und Osteostraci Norddeutschlands (Geschiebe) und Oesels. Acta Zoologica (Stockholm) 42: 73-150.

Gross W. 1966. Kleine Schuppenkunde. Neues Jahrbuch für Geologie und Paläontologie, Abhandlungen, 125: 29-48.

Gross W. 1968a. Beobachtungen mit dem Elektronenraster-Auflichtmikroskop an den Siebplatten und dem Isopedin von Dartmuthia (Osteostraci). Paläontologische Zeitschrift, 42(1/2): 73-82.

Gross W. 1968b. Fragliche Actinopterygier-schuppen aus dem Silur Gotlands. Lethaia, 1: 184218.

Gross W. 1971. Unterdevonische Thelodontier-und Acanthodier-Schuppen aus Westaustralien. Paläontologische Zeitschrift, 45(3-4): 97-106.

Gross W. 1973. Kleinschuppen, flossenstacheln und Zähne von Fischen aus Europäischen und Nordamerikanischen bonebeds des Devons. Palaeontographica Abt A 142: 51-155.

Günther A. 1871. Description of Ceratodus, a genus of ganoid fishes, recently discovered in rivers of Queensland, Australia. Phil. Trans. R. Soc. B 161, 511-571.

Hadiaty RK, Rachmatika I. 2003. Morphological study of Latimeria menadoensis scales. Treubia 33: $1-11$. 
Janvier P. 1996. Early Vertebrates. Oxford Scientific publications. pp 393. Clarendon Press, Oxford.

Jarvik E. 1972. Middle and Upper Devonian Porolepiformes from East Greenland with special reference to Glyptolepis groenlandica n. sp., and a discussion on the structure of the head in the Porolepiformes. Meddelelser om Grønland, 187(2), 1-307.

Jarvik E. 1980. Basic Structure and Evolution of Vertebrates, Volume 1. Academic Press, London, 575 pp.

Jerve A, Qu Q, Sanchez S, Blom H, Ahlberg PE. 2016. Three-dimensional paleohistology of the scale and median fin spine of Lophosteus superbus (Pander 1856). PeerJ, 4, e2521.

Jessen HL. 1968. Moythomasia nitida Gross und M. cf. striata Gross, Devonische Palaeonisciden aus dem oberen Plattenkalk der Bergisch-Gladbach-Paffrather Mudle (Rheinisches Schiefergebirge). Palaeontographica Abt A, 128: 87-114.

Johanson Z, Ritchie A. 2000. Rhipidistians (Sarcopterygii) from the Hunter Silstone (late Famennian) near Grenfell, NSW, Australia. Mitteilungen aus dem Museum für Naturkunde in Berlin. Geowissenschaftliche Reihe, 3: 111-136.

Johanson Z, Ahlberg PE, Ritchie A. 2013. First record of Porolepis (Sarcopterygii; porolepiformes) from eastern Gondwana. Canadian Journal of Earth Sciences, 50(3), 249-253.

Keating JN, Donoghue PCJ. 2016. Histology and affinity of anaspids, and the early evolution of the vertebrate dermal skeleton. Proceedings of the Royal Society B: Biological Sciences, 283: 20152917.

Keating JN, Marquart CL, Donoghue PCJ. 2015. Histology of the heterostracan dermal skeleton: Insight into the origin of the vertebrate mineralised skeleton. Journal of Morphology, 276: 657-680. 
Kemp A, Heaslop M, Carr A. 2015. Scale structure in the Australian lungfish, Neoceratodus forsteri (Osteichthyes: Dipnoi). Journal of morphology, 276(10): 1137-1145.

Kerr T, 1955. The scales of modern lungfish. Proceedings of the Zoological Society of London, $125(2), 335-345$.

Kind PK. 2011. The natural history of the Australian lungfish Neoceratodus forsteri (Krefft, 1870); pp. 61-96 in J. M. Jørgensen, J. Joss (eds), The biology of lungfishes. Enfield, NH: USA Science Publishers Inc.

Lebedev O, Lukševičs E. 2018. New materials on Ventalepis ketleriensis Schultze, 1980 extend the zoogeographic area of a Late Devonian vertebrate assemblage. Acta Geologica Polonica, 68(3), 437-454.

Lebedev A, Mark-Kurik E, Talimaa VN, Lukševičs E, Ivanov A. 2009. Bite marks as evidence of predation in early vertebrates. Acta Zoologica, 90, 344-356.

Long JA. 1989. A new rhizodontiform fish from the Early Carboniferous of Victoria, Australia, with remarks on the phylogenetic position of the group. Journal of Vertebrate Paleontology, 9(1): 1-17.

Märss T, Turner S, Karatajute-Talimaa V. 2007. Handbook of Paleoichthyology, Vol. 1B: ‘Agnatha' II Thelodonti. Munich: Verlag Dr Friedrich Pfeil.

Meunier FJ. 1980. Les relations isopédine-tissu osseux dans le post-temporal et les écailles de la ligne latérale de Latimeria chalumnae (Smith). Zool. Scripta, 9: 307-317.

Meunier FJ. 1981. "Twisted plywood" structure and mineralization in the scales of a primitive living fish Amia calva. Tissue and Cell, 13: 165-171.

Meunier FJ. 1984. Structure et minéralisation des écailles de quelques Osteoglossidae (Ostéichthyens, Téléostéens). Ann. Sc. Nat., Zool., 13ème Série, 6: 111-124.

Meunier FJ. 1987. Os cellulaire, os acellulaire et tissus dérivés chez les Osteichthyens: les phénomènes de l'acellularisation et de la perte de minéralisation. Ann. Biol., 26: 201-233. 
Meunier FJ, Brito PM. 2004. Histology and morphology of the scales in some extinct and extant teleosts. Cybium, 28(3): 225-235.

Meunier FJ, François Y. 1980. L'organisation spatiale des fibres de collagène et la minéralisation des écailles des Dipneustes actuels. Bull. Soc. Zool. Fr. 105, 215-226.

Meunier FJ, Gayet M. 1996. A new Polypteriforme from the Late Cretaceous and the middle Paleocene of South America. In: Mesozoic fishes- Systematics and Paleoecology (Arratia, G. \& Viohl, G., eds.), p. 95-103. Verlag Dr. F. Pfeil, München.

Meunier FJ, Gayet M. 1998. Rectification of the nomenclature of the genus name Pollia Meunier \& Gayet, 1996 (Osteichthyes, Cladistia, Polypteriformes) in Latinopollia nom. nov. Cybium, 22(2): 192.

Meunier FJ, Géraudie J. 1980. Les structures en contre-plaqué du derme et des écailles des vertébrés inférieurs. Annales Biologiques 19 (1): 1-18.

Meunier FJ, Poplin C. 1995. Paleohistological study of the scales of Amia robusta Priem, 1901,

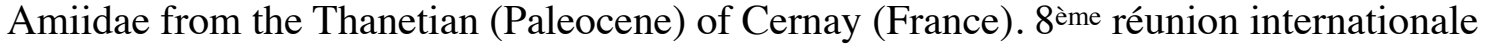
"Premiers Vertébrés-Vertébrés inférieurs", Paris 4/9 Septembre 1995, Géobios M.S. 19: $39-43$.

Meunier FJ, Zylberberg L. 1999. The structure of the external layer and of the odontodes of scales in Latimeria chalumnae (Sarcopterygii, Actinistia, Coelacanthidae) revisited using scanning and transmission electron microscopy. In: Séret B, Sire JY, editors, Proc. 5th Indo-Pacific. Fish Conf., Nouméa. 1997, Paris: Soc. Fr. Ichtyol., p. 109-116.

Meunier FJ, Erdmann MV, Fermon Y, Caldwell RL. 2008. Can the comparative study of the morphology and histology of the scales of Latimeria menadoensis and L. chalumnae (Sarcopterygii, Actinistia, Coelacanthidae) bring new insight on the taxonomy and the biogeography of recent coelacanthids? In: Cavin L, Longbottom A, Richter M, editors. Fishes and the Break-up of Pangaea . Geol. Soc., Lond., Spe. Public., 295: 351-360. 
Meunier FJ, Eustache R-P, Cavin L, Dutheil D. 2016. Histology of ganoid scales from the early Late Cretaceous of the Kem Kem beds, SE Morroco) : systematic and evolutionary implications. Cybium, 40(2) : 121-132.

Miller WA. 1979. Observations on the structure of mineralized tissues of the coelacanth, including the scales and their associated odontodes. The Biology and Physiology of the living Coelacanth. Occasional Papers of the California Academy of Sciences, 134, 68-78. Miller RF, Brazeau MD. 2007. A Late Devonian Porolepiform fish (Holoptychius) and the age of the Kennebecasis Formation, southern New Brunswick, Canada. Atlantic Geology, 43, $187-196$.

Millot J, Anthony J. 1958. Anatomie de Latimeria chalumnae. T. 1. Squelette, muscles et formations de soutien. 122 p (80 plates). CNRS Edr., Paris.

Millot J, Anthony J, Robineau D. 1978. Anatomie de Latimeria chalumnae. T. 3. Appareil digestif, pp 7-28 ; Téguments, écailles, pp 135-139. CNRS Edr., Paris.

Mondéjar-Fernández J. 2018. On cosmine : its origins, biology and implications for sarcopterygian interrelationships. Cybium, 42(1): 41-65.

Mondéjar-Fernández J. 2020. A new onychodont (Osteichthyes; Sarcopterygii) from the Middle Devonian of Morocco and its bearing on early osteichthyan evolution. Journal of Systematic Palaeontology, 18(7): 573-606.

Mondéjar-Fernández J, Clément G. 2012. Squamation and scale microstructure evolution in the Porolepiformes (Sarcopterygii, Dipnomorpha) based on Heimenia ensis from the Devonian of Spitzbergen. Journal of Vertebrate Paleontology, 32(2) : 276-284.

Mondéjar-Fernández J, Janvier P. 2014. Further evidence for the presence of holoptychiid porolepiforms (Sarcopterygii, Dipnomorpha) from the Frasnian of Colombia. C. R. Palévol, 13(7), 587-597. 
Mondéjar-Fernández J, Clément G, Sanchez S. 2014. New insights into the scales of the Devonian tetrapod Tulerpeton curtum Lebedev, 1984. Journal of Vertebrate Paleontology, 34(6): 1454-1459.

Mondéjar-Fernández J, Friedman M, Giles S. 2020. Redescription of the cranial skeleton of the Early Devonian (Emsian) sarcopterygian Durialepis edentatus Otto, 2007 (Dipnomorpha; Porolepiformes). Papers in Palaeontology. https://doi.org/10.1002/spp2.1315

Nelson JS. 2006. Fishes of the world John Wiley and Sons. Inc., Hoboken, New Jersey.

Neville AC. 1993. Biology of fibrous composites: development beyond the cell membrane. Cambridge University Press.

Onozato H, Watabe N. 1979. Studies on fish scale formation and resorption. III. Fine structure and calcification of the fibrillary plates of the scales in Carassius auratus (Cypriniformes: Cyprinidae). Cell Tissue Research, 201: 409-422.

O'Shea J, Keating JN, Donoghue PCJ. 2019. The dermal skeleton of the jawless vertebrate Tremataspis mammillata (Osteostraci, stem-Gnathostomata). Journal of morphology, 280(7): 999-1025.

Ørvig T. 1957. Remarks on the vertebrate fauna of the Lower Upper Devonian of Escuminac Bay, P.Q., Canada, with special reference to the Porolepiform Crossopterygians. Ark. Zool., 10(6): 367-426.

Ørvig T. 1966. Histologic studies of ostracoderms, placoderms and fossil elasmobranchs. 2. On the dermal skeleton of two late Palaeozoic elasmobranchs. Arkiv för Zoologi, 19(1): 1-39.

Ørvig T. 1969. Vertebrates from the Wood Bay Group and the position of the Emsian-Eifelian boundary in the Devonian of Vestspitsbergen. Lethaia, 2, 273-328.

O'Shea J, Keating JN, Donoghue PC. (2019). The dermal skeleton of the jawless vertebrate Tremataspis mammillata (Osteostraci, stem-Gnathostomata). Journal of Morphology, 280(7): 999-1025. 
Pander CH. 1856. Monographie der fossilen Fische des silurischen Systems der russischbaltischen Gouvernements. St Petersburg: Akademie der Wissenschaften.

Pearson DM. 1982. Primitive bony fishes, with especial reference to Cheirolepis and palaeonisciform actinopterygians. Zoological Journal of the Linnean Society, 74(1): 35-67.

Pridmore PA, Barwick RE. 1993. Post-cranial morphologies of the Late Devonian dipnoans Griphognathus and Chirodipterus and locomotor implications. Memoirs of the Association of Australasian Palaeontologists, 15: 161-182.

Qu Q, Zhu M, Wang W. 2013. Scales and dermal skeletal histology of an early bony fish Psarolepis romeri and their bearing on the evolution of rhombic scales and hard tissues. PloS one, 8(4): e61485. doi:10.1371/journal.pone.0061485

Qu Q, Sanchez S, Zhu M, Blom H, Ahlberg PE. 2017. The origin of novel features by changes in developmental mechanisms: ontogeny and three-dimensional microanatomy of polyodontode scales of two early osteichthyans. Biological Reviews, 92(2), 1189-1212.

Roux GH. 1942. The microscopic anatomy of the Latimeria scale. South Afri. J. Med. Sci., 7: $1-18$.

Sansom IJ, Donoghue PCJ, Albanesi G. 2005. Histology and affinity of the earliest armoured vertebrate. Biology Letters, 1(4): 446-449.

Schultze H-P. 1966. Morphologische und histologische Untersuchungen an Schuppen mesozoischer Actinopterygier (Übergang von Ganoid- zu Rundschuppen). N. Jb. Geol. Paläont. Abh., 126(3), 232-314.

Schultze H-P. 1968. Palaeoniscoidea-Schuppen aus dem Unterdevon Australiens und Kanadas und aus dem Mitteldevon Spitsbergens. Bulletin of the British Museum of Natural History (Geology), 16: 343-368

Schultze H-P. 1977. Ausgangsform und Entwicklung der rhombischen Schuppen der Osteichthyes (Pisces). Pala“ontologische Zeitschrift 51: 152-168. 
Schultze HP. 1980. Crossopterygier-Schuppen aus dem obersten Oberdevon Lettlands

(Osteichthyes, Pisces). Neues Jahrbuch für Geologie und Paläontologie, Monatshefte, 4, $215-228$.

Schultze HP. 1996. The scales of Mesozoic actinopterygians. In: Arratia G, Viohl G, editors Mesozoic fishes - Systematics and Paleoecology. Verlag Dr F. Pfeil, München, Germany. p. 83-93.

Schultze HP. 2000. A porolepiform rhipidistian from the Lower Devonian of the Canadian Arctic. Fossil Rec., 3: 99-109.

Schultze HP. 2015. Scales, enamel, cosmine, ganoine, and early osteichthyans. C. R. Palevol, 15(1-2): 83-102.

Schultze HP. 2018. Hard tissues in fish evolution: history and current issues. Cybium, 42(1): 29-39.

Schultze HP, Arsenault M. 1987. Quebecius quebecensis (Whiteaves), a porolepiform crossopterygian (Pisces) from the Late Devonian of Québec, Canada. Canadian Journal of earth. Sciences, 24, 2351-2361.

Sherman VR, Quan H, Yang W, Ritchie RO, Meyers MA. 2017. A comparative study of piscine defense: the scales of Arapaima gigas, Latimeria chalumnae and Atractosteus spatula. Journal of the Mechanical Behavior of Biomedical Materials, 73, 1-16.

Sire JY. 1989. Scales in young Polypterus senegalus are elasmoid: new phylogenetic implications. American Journal of Anatomy, 186(3): 315-323.

Sire JY. 1990. From ganoid to elasmoid scales in the actinopterygian fishes. Neth. J. Zool., 40: $75-92$.

Sire JY \& Huysseune A. 2003. Formation of dermal skeletal and dental tissues in fish: a comparative and evolutionary approach. Biological Reviews 78: 219-249. 
Sire JY, Donoghue PC, Vickaryous MK. 2009. Origin and evolution of the integumentary skeleton in non-tetrapod vertebrates. Journal of Anatomy, 214(4): 409-440.

Smith MM, Hall BK. 1990. Development and evolutionary origins of vertebrate skeletogenic and odontogenic tissues. Biological Reviews, 65(3): 277-373.

Smith MM, Hobdell MH, Miller WA. 1972. The structure of the scales of Latimeria chalumnae. J. Zool., London, 167: 501-509.

Song J, Ortiz C, Boyce MC. 2011. Threat-protection mechanics of an armored fish. Journal of the mechanical behavior of biomedical materials, 4(5): 699-712.

Wang N-Z, Dong Z-Z. 1989. Discovery of Late Silurian microfossils of Agnatha and fishes from Yunnan, China. Acta Paleontologica Sinica, 28: 192-206

Wang N-Z, Donoghue PCJ, Smith MM, Sansom IJ. 2005. Histology of the galeaspid dermoskeleton and endoskeleton, and the origin and early evolution of the vertebrate cranial endoskeleton. Journal of Vertebrate Paleontology 25: 745-756.

Williamson WC. 1849. XXIII. On the microscopic structure of the scales and dermal teeth of some Ganoid and Placoid Fish. Philosophical Transactions of the Royal Society of London, 139: 435-475.

Williamson WC. 1851. Investigations into the structure and development of the scales and bones of fishes. Philosophical Transactions of the Royal Society of London, 141: 643-702.

Yang W, Chen IH, Gludovatz B, Zimmermann EA, Ritchie RO, Meyers MA. 2013. Natural flexible dermal armor. Advanced Materials, 25(1): 31-48.

Young GC. 2010. Placoderms (armored fish): dominant vertebrates of the Devonian period. Annual Review of Earth and Planetary Sciences, 38, 523-550.

Young GC, Long JA, Ritchie A. 1992. Crossopterygian fishes from the Devonian of Antarctica: Systematics, relationships and biogeographic significance. Records of the Western Australian Museum Supplement, 14: 1-77. 
Young GC, Burrow CJ, Long JA, Turner S, Choo B. 2010. Devonian macrovertebrate assemblages and biogeography of East Gondwana (Australasia, Antarctica). Palaeoworld, 19: $55-74$.

Zhu M, Yu XB, Wang W, Zhao WJ, Jia LT. 2006. A primitive fish provides key characters bearing on deep osteichthyan phylogeny. Nature, 441: 77-80.

Zhu M, Zhao W, Jia L, Lu J, Qiao T, Qu Q. 2009. The oldest articulated osteichthyan reveals mosaic gnathostome characters. Nature, 458: 469-474.

Zhu M, Wang W, Yu XB. 2010. Meemannia eos, a basal sarcopterygian fish from the Lower Devonian of China-expanded description and significance; pp 199-214, in Elliott DK, Maisey JG, Yu X, Miao D. (eds.), Morphology, Phylogeny and Paleobiogeography of Fossil Fishes. München: Verlag Dr. Friedrich Pfeil.

Zimmermann EA, Gludovatz B, Schaible E, Dave NK, Yang W, Meyers MA, Ritchie RO. 2013. Mechanical adaptability of the Bouligand-type structure in natural dermal armour. Nature communications, $4(1): 1-7$.

Zylberberg L. 1988. Ultrastructural data on the scales of the dipnoan Protopterus annectens (Sarcopterygii, Osteichthyes). Journal of Zoology, 216(1): 55-71.

Zylberberg L, Nicolas G. 1982. Ultrastructure of scales in a teleost (Carassius auratus L.) after use of rapid freere-fixation and freeze-substitution. Cell Tissue Research, 223: 349-367.

Zylberberg L, Wake MH. 1990. Structure of the scales of Dermophis and Microcaecilia (Amphibia: Gymnophiona), and a comparison to dermal ossifications of other vertebrates. Journal of Morphology, 206(1): 25-43.

Zylberberg L, Meunier FJ, Laurin M. 2010. A microanatomical and histological study of the postcranial dermal skeleton in the Devonian sarcopterygian Eusthenopteron foordi. Acta Palaeont. Polonica, 55 (3): 459-470. 
Zylberberg L, Meunier FJ, Laurin M. 2015. A microanatomical and histological study of the postcranial dermal skeleton of the Devonian actinopterygian Cheirolepis canadensis. Acta Palaeontologica Polonica, 61(2): 363-376.

Zylberberg L, Géraudie J, Meunier FJ, Sire JY. 1992. Biomineralization in the integumental skeleton of the living lower Vertebrates. In: Hall BK, editor. Bone, CRC Press, 4: 171-224. 


\section{FIGURES}

\section{Figure captions}

Figure 1. The scales of the holoptychiid porolepiform Holoptychius. A. Reconstruction of Holoptychius sp. (modified after Jarvik 1980). B. Detail of the squamation of Holoptychius jarviki from the Escuminac Formation of Miguasha (Québec) (modified from Ørvig 1957). Note the imbricate scales and the variability of the superficial ornamentations of the exposed area (from tubercles to ridges). Anterior to the left. Scale bar $=10 \mathrm{~mm}$. C-D. Isolated scales of Holoptychius sp. (MNHN, URSS, 5075) from the Frasnian of Latvia in external view (C) and internal view (D). E-F. Isolated scales of Holoptychius cf. nobilissimus (MB.f. 1994.1) from the Givetian-Frasnian of Latvia in external view $(\mathbf{E})$ and internal view (F). Arrows point anteriorly. Scale bar $=10$ mm. G. Scales of Holoptychius sp. (MNHN-F-HISTOS 2736) from the FrasnianFamennian of Greenland still embedded in sediment. Arrow points to the selected scale detailed in Fig. 2C. Scale bar $=10 \mathrm{~mm}$.

Figure 2. Vertical cross sections of the scales of Holoptychius. A. Longitudinal cross section of MNHN-F-HISTOS 2737. Note that the laminated basal plate is crossed by vascular canals that are perpendicular to the collagenous layers. Arrow points anteriorly. B. Transversal cross section of MNHN-F-HISTOS 2740. Note that the surface of the superficial bony layer displays round reliefs that correspond to the antero-posterior ridges ornamenting the exposed area (see Fig. 1E). C. Transversal cross section of MNHN-F-HISTOS 2736. Square inset detailed in Fig. 3. Arrow heads indicate the occurrence of post-mortem cracks separating the superficial layer and the basal plate. Abbreviations: bp, basal plate; lb, lamellar bone; vb, vascular bone; sl, superficial layer; vc, vascular canal. Scale bar $=5 \mathrm{~mm}$. 
Figure 3. Vertical cross section of the scales of Holoptychius. Detail of the transversal cross section of the posterior field of Holoptychius sp. (MNHN-F-HISTOS 2736) showing the stratified basal plate overlaid by the ornamented superficial layer. Note that the bony layer is abundantly vascularised and numerous osteocytes can be seen. Black arrow-heads in the basal plate point to ascending vascular canals that merge with the vascular canals of the superficial bony layer. Abbreviations as in Fig. 2. Scale bar $=100 \mu \mathrm{m}$.

Figure 4. Histological organization of the scales of Holoptychius in vertical cross section. A. Detail of the superficial layer and basal plate showing the organization of the bony tissue (MNHN-F-HISTOS 2736). Numerous vascular cavities (vc) and star-shaped osteocytes (pointed by arrow heads) occur in the vascular bone of the superficial layer. The basal plate is formed by lamellar bone in which the collagen plies (pointed by asterisks) are arranged in parallel. Scale bar $=50 \mu \mathrm{m}$. B. Detail of the superficial layer showing a secondary vascular canal (the asterisk indicates the light of the vascular canal) with osteocytes (pointed by black arrow heads) occurring in its bony walls (MNHN-F-HISTOS 2739). Scale bar $=50 \mu \mathrm{m}$. C. Detail of the osteocytes from the vascular bone of the superficial layer and their ramified osteocytic canalicles (MNHN-F-HISTOS 2736). Scale bar $=20 \mu \mathrm{m}$. D. Detail of the basal plate showing four ascending vascular canals that cross the successive collagenous layers (indicated by black arrows) in which many thin parallel ascending collagenous fibres (pointed by white arrow heads) are also seen (MNHN-F-HISTOS 2736). Scale bar $=50 \mu \mathrm{m}$. Inset, detail of an ascending vascular canal (MNHN-F-HISTOS 2737). Scale bar $=25 \mu \mathrm{m}$. E. Detail of the elongate osteocytes (elasmocytes) from the basal plate embedded between the lamellae of the isopedine (MNHN-F-HISTOS 2737). Scale bar $=50 \mu \mathrm{m}$. 
Figure 5. Organization of the basal plate of the scales of Holoptychius. A. Detail of three compound collagenous fibres (MNHN-F-HISTOS 2737). Each fibre is constituted of several collagenous units (fibrils) forming a bundle. Scale bar $=5 \mu \mathrm{m}$. B. Vertical cross section of the posterior field of a scale showing the successive layers of the isopedine (MNHN-F-HISTOS 2736). The arrows point to layers where the thick collagenous fibres are cut at a right angle. These specific layers occur every five layers. Scale bar $=50 \mu \mathrm{m}$. C. Schematic representation of an oblique cross section through the isopedine of the basal plate. Numbers correspond to the arrangement of the layers from top (earliest deposited layers) to bottom (latest deposited layers). Note that the black arrows from B match the fibres cut perpendicularly. The grey and black fibres represent the even and odd system of layers respectively, resulting in arciform patterns in cross section evidencing a double-twisted plywood arrangement of the collagen layers (cf). Cellular spaces (bp.c, basal plate cells) occur between the layers. D. Oblique section of the basal plate (MNHN-F-HISTOS 2738). Note that the direction of the collagenous layers changes from one layer to the next. The resulting rods form arciform patterns (dashed lines) that characterise a double-twisted plywood-like organization. The asterisks point to ascending vascular canals. Arrow points towards the external surface (top) of the scale. Scale bar $=500 \mu \mathrm{m}$. E. Model of an oblique section through the isopedine of the basal plate. Each pair of layers $(1 / 2,3 / 4$, etc.) form successive roughly orthogonal plies and their orientation progressively rotates of approximately $36^{\circ}$ in the direction of the arrows (clockwise from top to bottom). The grey and black lines correspond to the even and odd systems respectively and match the arciform patterns in C. F. Model of an oblique section in which the even and odd systems of layers have been separated. Note the progressive rotation of the fibres in each system and the resulting intermingled arched patterns. Abbreviations: bp.c, basal plate cell; cf, collagen fibre. 
Figure 6. Simplified phylogeny of selected osteichthyans highlighting the evolution of the scale shape and microstructural features related to the basal plate (as discussed in the text).

Phylogenetic hypotheses after Friedman \& Brazeau 2010 and Clement et al. 2018. Drawings not to scale, modified after Kerr 1955 (Neoceratodus); Schultze 1968 (Dialipina, Ligulalepis, Orvikuina), 2018 (Lophosteus, Amia, Holoptychius); Jarvik 1980 (Eusthenopteron, Osteolepis, Porolepis); Pearson 1982 (Cheirolepis); Gardiner 1984 (Moythomasia); Janvier 1996 (Dipterus); Witzmann 2011 (Panderichthys); Qu et al. 2013 (Andreolepis, Psarolepis); Mondéjar-Fernández et al. 2014 (Tulerpeton); Mondéjar-Fernández 2020 (Selenodus). Asterisks indicate taxa displaying the elasmoid scale morpho-histotype. Abbreviations: -min, partially mineralized isopedine; A, actinopterygians; $\mathbf{D}$, dipnomorphs; $\mathbf{d t}$, double-twisted arrangement of the layers; $\mathbf{i}$, isopedine (i.e., lamellar tissue with a plywood-like arrangement of the collagen layers); $\mathbf{o}$, orthogonal arrangement of the layers; $\mathbf{S}$, sarcopterygians; $\mathbf{t}$, twisted arrangement of the layers; $\mathbf{T}$, tetrapodomorphs. 